\title{
The History and International Relations of American and French Missionary Universities in the Middle East and East Asia as a Case of Transnational Professional Relations
}

\begin{abstract}
This article combines History (the discipline) research with International Relations (subdiscipline of Political Science, my point of departure) for transnational studies research on longterm developments of transnational professional relations between the USA/Europe and the Middle East and East Asia through missionary universities. American Protestant and French Catholic missionaries were important transnational intellectuals and professionals who founded universities in the late 1800s and early 1900s. These universities continue to educate generations of transnational professionals. The article seeks to contribute in particular to the transnational studies dimension of International Relations drawing on educational, social and cultural history. The article concludes by seeking to draw lessons from this research for current higher education policy in the Global South, where the combination of historical material and International Relations concepts offers important lessons. ${ }^{1}$
\end{abstract}

\section{Introduction: Combining International Relations and History}

This article is part of International Relations (sub-discipline of Political Science), research on American, French and other foreign-affiliated universities in the Middle East and East Asia as transnational actors with soft power towards both Western and Eastern societies. Soft power is based on attraction to, for instance, culture and policy, unlike hard military or economic power through coercion or inducement. ${ }^{2}$ This research seeks to contribute to understanding the role of universities as transnational actors between Eastern and Western societies and the extent and limitations of their soft power in societies in the East and the West. International Relations is the point of departure for this research on transnational actors and the role they play in transnational relations between societies to contribute to International Relations theory on transnational actors and their soft power.

For this special issue, the focus is on transnational professional relations which gives the opportunity to explore that particular dimension of transnational academic relations. These educational missionaries who founded universities in the Middle East and East Asia were important transnational educational professionals - who have and continue to educate and

\footnotetext{
1 The Global North refers to countries with a high level of human development according to the United Nations Development Programme Human Development Report. These countries are predominantly in the Northern Hemisphere. The Global South refers to the rest of countries which are mostly situated in the southern Hemisphere in Africa, Asia and Latin America. Harold Damerow, "Global North and Global South. Definitions," Union County College, http://faculty.ucc.edu/egh-damerow/global south.htm (accessed 09/20, 2015). . 2 Joseph S. Nye Jr., Soft Power: The Means to Success in World Politics, 1st ed ed. (New York: Public Affairs, 2004), 191.
} 
shape transnational professionals educated from their universities in the Middle East and East Asia.

The first American Protestant missionary higher education institution in the Middle East was Robert College founded in Istanbul in 1863 by American Protestant educators and philanthropists, which is illustrative of the American Protestant missionary educational activities at the basis of the historical American universities mentioned in this article. Robert College was taken over by the Turkish Republic in 1971 as Boğaziçi University. The name of Robert College continues as an American high school. Boğaziçi University and Robert College (high school) have high status in Turkish society today and an American profile. In 1866, the Syrian Protestant College was founded by American Protestant educators in the Levant. It was renamed American University of Beirut (AUB) in 1920. Shortly after the Université Saint-Joseph de Beyrouth was founded in 1875 by Francophone Jesuits. The American University in Cairo was founded in 1919 by American Protestant missionary educators and philanthropists similar to the founders of Robert College and AUB. ${ }^{3}$ These universities continue to be some of the most important higher education and research institutions in the Middle East. Before the Korean War, there was more than 20 American missionary higher education institutions in China, where prominent examples were St John's University in Shanghai (founded in 1879) or Yenching University (founded 1919). There was also active Catholic higher education in China, where today's prominent Fudan University in Shanghai was founded as the Francophone Jesuit Université Aurore in 1903. Neither the People's Republic of China nor the US government tolerated such bicultural and binational institutions during the Korean War, but these universities live on in important public universities of the PRC. ${ }^{4}$

To make both the broader contribution and the specific contribution on professional relations here, this research looks at the founding and development of transnational American and French missionary universities in the Middle East and East Asia in the late 1800s and early 1900s. This International Relations research draws extensively on History and its research on these universities. Academic disciplines are capitalized here to distinguish International Relations or History as academic disciplines from their objects. My research and the article is based on the view that History provides valuable empirical material on long-term developments for Political Science research which can suffer from a lack of historical perspective and short time series. Political Science (and its sub-discipline International Relations including research on transnational actors and relations) is focused on developing general concepts and theories, where longer time-series are useful. International Relations research discovered transnational relations with Joseph S. Nye and Robert O. Keohane's 1971 special issue of International Organization, but political science transnational studies can suffer

\footnotetext{
3 Bayard Dodge, The American University of Beirut; a Brief History of the University and the Lands which it Serves (Beirut: Khayat's, 1958), 127.; Lawrence R. Murphy, The American University in Cairo, 1919-1987 (Cairo: American University in Cairo Press, 1987), 288.; Carla Eddé, L'USJ: Portrait d'Une Université (Beyrouth: Presses de l'Université Saint-Joseph, 2000), 159.

4 Philip West, Yenching University and Sino-Western Relations, 1916-1952 (Cambridge, MA: Harvard University Press, 1976).
} 
from lack of historical perspective, or "presentism". ${ }^{5}$ In parallel, History is also turning more to transnational history, where the longer-standing historical developments are naturally clear. It is also thought-provoking for a political scientist to see the references to International Relations literature. ${ }^{6}$ There is clearly much mutual benefit from closer engagement of transnational studies in International Relations and History.

This article analyzes American Protestant and French Catholic missionaries and their universities as transnational agents using History. The article contributes to answering International Relations questions of how these missionaries and their universities created transnational flows of ideas, information, talent and money between the West, the Middle East and East Asia. The article contributes on integrating International Relations and History literature as well as literature on American and French educational engagement in the Middle East and East Asia. The literature on these universities is historical and not part of the International Relations literature on transnational relations between the West and the East.

This research started as contemporary International Relations research on the soft power of the American and French universities in the Middle East, which then took a longer historical view of these institutions. Such a longer historical allows for the comparison with the Western institutions in China before the Korean War. This research employs longitudinal, comparative, historical case studies of universities. The research follows the development of these universities in the Middle East and East Asia from their founding to the present day or their closing or nationalization and possible legacy thereafter (this is what is meant by longitudinal, historical case studies). This research included field research in Beirut in August-September 2008, in Cairo in December 2008, the United Arab Emirates in April 2009 and interviews in Boston, New York and Washing DC with a total of 100 interviews with academics, administrators, congressional aids, diplomats, lobbyists, trustees, for the Middle Eastern universities. The interviews were semi-structured around the interactions between the university and public, private and civil society actors in both the Middle East host society and in American or French society. Many of the interview persons had decades of experience with the place of their institution between the Middle East and the West, so the interviews had character of oral histories of these interactions with Middle Eastern and Western actors. The interviews were conducted under conditions of no identifiable reference to any interview person. The research did not include archival research. The contemporary role of the American

\footnotetext{
5 Joseph S. Jr Nye and Robert O. Keohane, "Transnational Relations and World Politics: An Introduction," International Organization 25, no. 3, Transnational Relations and World Politics (1971), 329-349.; Fred Halliday, "The Romance of Non-State Actors," in Non-State Actors in World Politics, eds. Daphné Josselin and William Wallace (Basingstoke; New York: Palgrave, 2001), 21-37.

6 Patricia Clavin, "Defining Transnationalism," Contemporary European History 14, no. 4 (2005), 421-439. doi:10.1017/S0960777305002705.

https://www.cambridge.org/core/article/definingtransnationalism/CFDA72A369D7C161034D363656646315.; Erik Van Der Vleuten, "Toward a Transnational History of Technology: Meanings, Promises, Pitfalls," Technology and Culture 49, no. 4 (2008), 974-994.; Pierre-Yves Saunier, Transnational HistoryPalgrave Macmillan, 2013).
} 
universities for soft power purposes has got attention in recent policy literature. ${ }^{7}$ The academic International Relations literature on soft power or transnational relations has not touched upon the longer historical developments of neither the Middle Eastern nor the Asian universities. The longitudinal study draws on literature on these universities, which includes academic studies, ${ }^{8}$ somewhat official institutional histories, ${ }^{9}$ and accounts by university presidents and professors. ${ }^{10}$ The combination of this material allows for a longitudinal study of the transnational relations of these universities between the West, the Middle East and Asia.

The research compares these longitudinal case studies between universities within and between the Middle East and East Asia. This approach is chosen to counter the pitfall of

7 Joseph S. Nye Jr. and William A. Owens, "America's Information Edge," Foreign Affairs 75 (1996), 20-36.; "Remarks at the U.S. University Presidents Summit on International Education Dinner. Washington DC," last modified 5 January 2006, accessed 11/22, 2006,

http://www.state.gov/secretary/rm/2006/58750.htm.; Center for Strategic \& International Studies, Smart Power in the Obama Administration: The Role of International Education and Exchange, Smart Power in the Obama Administration: The Role of International Education and Exchange, 2009 Center for Strategic \& International Studies.

8 Munir Antonios Bashshur, "The Role of Two Western Universities in the National Life of Lebanon and the Middle East: A Comparative Study of the American University of Beirut and the University of Saint-Joseph" (Doctor of Philosophy, University of Chicago, 1964), .; Jessie Gregory Lutz, China and the Christian Colleges 1859-1950 (New York: Cornell University Press, 1971).; West, Yenching University and Sino-Western Relations, 1916-1952; Nadim G. Khalaf, The Economics of the American University of Beirut: A Study of a Private University in the Developing World (Beirut: American University of Beirut, 1977), 99.; Faith M. Hanna, An American Mission: The Role of the American University of Beirut (Boston: Alphabet Press, 1979), 123.; Corinne de Ménonville, Les Aventuriers De Dieu Et De La République: Consuls Et Missionnaires En Chine (1844-1937) (Paris: Les Indes Savantes, 2007).; Ussama Samir Makdisi, Artillery of Heaven : American Missionaries and the Failed Conversion of the Middle East (Ithaca: Cornell University Press, 2008), 262.; Daniel H. Bays and Ellen Widmer, eds., China's Christian Colleges: Cross-Cultural Connections, 1900-1950 (Stanford: Stanford University Press, 2009), 432.; Betty Signe Anderson, The American University of Beirut: Arab Nationalism and Liberal Education (Austin: University of Texas Press, 2011), 254.

9 Murphy, The American University in Cairo, 1919-1987, 288; Eddé, L'USJ: Portrait d'Une Université, 159

10 Bayard Dodge, The American University of Beirut; an Introduction to Beirut and the University (Princeton?: N.J., 1952), 117.; Dodge, The American University of Beirut; a Brief History of the University and the Lands which it Serves, 127; Stephen Beasley Linnard Penrose, That they may have Life; the Story of the American University of Beirut, 1866-1941 (Beirut: American University of Beirut, 1970), 347.; John Murchison Munro, A Mutual Concern: The Story of the American University of Beirut (Delmar, NY: Caravan Books, 1977), 198.; Sélim Abou, "L'USJ 125 Ans Après : Les Défis Et l'Espoir," in Les Libertés : Discours Annuels De Recteur De l'Université Saint-Joseph De 1996 à 2003, ed. Sélim Abou (Beyrouth: Presses de l'Université Saint-Joseph, 2000), 101-124.; Sélim Abou, Les Libertés : Discours Annuels De Recteur De l'Université Saint-Joseph De 1996 à 2003 (Beyrouth: Presses de l'Université SaintJoseph, 2003), 201. 
"presentism"11 in transnational relations research in International Relations. "Presentism" is the unfortunate tendency in Political Science to look at the present and recent past with little regard for the effects of longer preceding historical developments. "Presentism" is often the lack of recognition of historical cases of a phenomenon, which is then wrongly identified as new. These missionary universities are a clear example that transnational relations have a longer history than is usually acknowledged in International Relations. Historically-informed research shows the historical roots of current transnational professional relations. Above, I mentioned, that the soft power of American universities in the Middle East has attracted policy attention. This policy attention was acute caused by the War on Terror and with no sense of the long historical developments of these transnational relationships through these universities. Equally, many countries have in recent years worked to develop higher education and research ties with China with little or no sense of historical ties in these domains.

The topic of this special issue is transnational professional relations. And this study focuses on a key aspect of this theme: the dream of professional life based on higher education is strong in emerging and developing countries in the Global South, including the Middle East and East Asia. ${ }^{12}$ The Global South has seen a great expansion of private higher education, often with a transnational element. ${ }^{13}$ In the spirit of the Harvard Kennedy School of Government and the United Nations University of applying basic research across social, human, natural and other sciences to policy questions, I seek to apply my results to higher education policy questions for the Global South. The history and politics of the important historical missionary universities here have important lessons for current higher education policy questions. These lessons will be outlined in the end, where they will show the relevance of History and International Relations to the higher education policy questions highlighted by, for instance, the World Bank above of great importance to millions and millions of individuals and families throughout the world today.

\section{Combining History and International Relations Research on Transnational Universities, Intellectuals and Professionals}

In International Relations, transnational relations contrast with international relations. The latter are relations between states, questions of inter-state war and peace and traditional diplomacy. Transnational relations are the cross-border relations of other actors in society. One early and key definition of transnational relations is Joseph S. Nye and Robert Keohane's definition of transnational relations as "global interactions" of information, people, money and

\footnotetext{
11 Fred Halliday, "The Romance of Non-State Actors," in Non-State Actors in World Politics, eds. Daphné Josselin and William Wallace (Basingstoke; New York: Palgrave, 2001), 21-37. 12 World Bank, The Road Not Travelled: Education Reform in the Middle East (Washington, DC: ,[2008]):; "Education for the Knowledge Economy," The World Bank Group, last modified 2009-03-01, accessed 04/03, 2016, http://go.worldbank.org/I8T7C0VPV0.

13 Philip G. Altbach, ed., Private Prometheus : Private Higher Education and Development in the 21st Century, Vol. 77 (Westport, Conn.: Greenwood Press, 1999), 237.; Philip G. Altbach and Daniel Levy, eds., Private Higher Education: A Global Revolution (Rotterdam, Taipei: Sense Publishers, 2005).
} 
goods moving between non-state actors across borders. ${ }^{14}$ Nye and Keohane's 1971 special issue of International Organization on transnational relations made a paradigmatic difference in International Relations by introducing the concept of transnational relations and changing the paradigm from inter-state relations to cross-border relations between other actors. Here it is important to distinguish between introducing a new analytical concept and discovering a new empirical phenomenon. Historians will be well aware that transnational relations are an old empirical phenomenon, where political scientists equipped with the new analytical concept of transnational relations from Nye and Keohane are prone to confuse it is an empirical novelty. Political scientists easily fall into the trap of declaring that International Relations are then no longer only about the state and the emergence of new non-state actors, which generally reflects lack of historical knowledge. Research on transnational relations has developed by leaps and bounds since the 1971 special issue of International Organization, where Nye and Keohane presented this definition. Nye and Keohane's early key definition is useful to immediately point out transnational aspects to universities: they can be deeply engaged in moving information, people and money across borders. The missionary universities in this study are important cases of transnational actors. The existing historiography of these Middle Eastern and Asian universities and my own research have described how they have historically been and still are bridges between societies which carry information, people and money in both directions.

These universities and their histories are useful cases for International Relations research on transnational actors and their soft power, although they have been lost in the fog of time for most political scientists researching transnational actors and soft power. I have used these cases to explore the precise extent and limitations and basis of the soft power of such transnational actors both towards the Eastern host society and the Western sponsoring society and their relations with both Eastern host state and Western sponsoring state. ${ }^{15}$ Transnational relations research has grown significantly since the introduction by Nye and Keohane with the

14 Joseph S. Jr Nye and Robert O. Keohane, "Transnational Relations and World Politics: An Introduction," International Organization 25, no. 3, Transnational Relations and World Politics (1971): 329-349.

15 Rasmus Gjedss $\emptyset$ Bertelsen, "The Effect of Public and Private Decisions on University Governance on the Transnational Relations of American-Associated Universities in the Middle East," Revue Des Mondes Musulmans Et De La Méditerannée 131, no. 1 (2012), 45-62.; Rasmus Gjedss $\varnothing$ Bertelsen, "Private Foreign-Affiliated Universities, the State and Soft Power: The American University of Beirut and the American University in Cairo," Foreign Policy Analysis 8, no. 3 (2012), 293-311.; Rasmus Gjedssø Bertelsen, "American Missionary Universities in China and the Middle East and American Philanthropy: Interacting Soft Power of Transnational Actors," Global Society 28, no. 1 (Special Issue: American Philanthropy and the Hard, Smart and Soft Power of the United States) (2014), 113-127.; Rasmus Gjedss $\varnothing$ Bertelsen, "The University as a Transnational Actor with Transnational Power: American Missionary Universities in the Middle East and China," PS: Political Science \& Politics, no. July (2014), 624-627.; Rasmus Gjedssø Bertelsen, "The Political Context for Transnational Actor Soft Power: Classical American Overseas Missionary Universities and the State," in China and the World: Theatres of Soft Power, eds. Naren Chitty and Luo Qing (Beijing: Communication University of China, 2015), 161-172.; Rasmus Gjedssø Bertelsen, "The American University of Beirut: A Case for Studying Universities in International Politics," in One Hundred and Fifty, eds. Nadia Maria El Cheikh, Lina Choueiri and Bilal Orfali (Beirut: AUB Press, 2016), 133-142. 
International Organization issue in 1971. One important step in this development is the scholarship by Thomas Risse-Kappen ${ }^{16}$ and colleagues or by Daphné Josselin and William Wallace, which both show the (supposedly) increasing importance of transnational actors. ${ }^{17}$ This scholarship has little historical memory and perspective of historical transnational actors in general (Halliday's warning of "presentism"). Universities are only beginning to receive attention as current or historical transnational actors, which is surprising taking into account the interest in epistemic and expert communities. ${ }^{18}$

In the Middle East, during the late 1800s and early 1900s, American Protestant and French or Francophone Catholic missionaries founded universities. The American Protestant missionary activity was the culmination of American Protestant missionary activity overseas from the mid1800, which was the outcome of religious revival in American society. ${ }^{19}$ The Jesuits have a centuries old international educational tradition, where Francophone Jesuit education became intertwined with French strategic use of education for foreign policy reasons. In the 1840s, the French consul in Beirut complained of the increasing educational activity of American Protestants and urged the Jesuits to respond to protect the relative position of French language. ${ }^{20}$ Corinne de Ménonville's study of the interaction of French consuls and French and Francophone Jesuit educators in China in the 1800s and early 1900s is fittingly titled "Les Aventuriers de Dieu et de la République: Consuls et missionnaires en Chine (1844-1937)" [The

16 Thomas Risse-Kappen, "Bringing Transnational Relations Back in: Introduction," in Bringing Transnational Relations Back in: Non-State Actors, Domestic Structures and International Institutions, ed. Thomas Risse-Kappen (Cambridge: Cambridge University Press, 1995), 3.

17 Daphné Josselin and William Wallace, "Non-State Actors in World Politics: A Framework," in Non-State Actors in World Politics, eds. Daphné Josselin and William Wallace (Basingstoke; New York: Palgrave, 2001), 1-20.

18 Emanuel Adler and Peter M. Haas, "Conclusion: Epistemic Communities, World Order, and the Creation of a Reflective Research Program," International Organization 46, no. 1, Knowledge, Power, and International Policy Coordination (Winter) (1992), 367-390.; Peter M. Haas, "Introduction: Epistemic Communities and International Policy Coordination," International Organization 46, no. 1 (1992), 1-35.; Diane Stone, "Private Authority, Scholarly Legitimacy, and Political Credibility: Think Tanks and Informal Diplomacy," in Non-State Actors and Authority in the Global System, eds. Richard A. Higgott, Geoffrey R. Underhill and Andreas Bieler (London: Routledge, 1999), 211-225.; Diane Stone, "The 'Policy Research' Knowledge Elite and Global Policy Processes," in Non-State Actors in World Politics, eds. Daphné Josselin and William Wallace (Basingstoke; New York: Palgrave, 2001), 113-132.;

Peter M. Haas, "Epistemic Communities," in International Encyclopedia of Political Science, eds. Bertrand Badie, Dirk Berg-Schlosser and Leonardo Morlino (Thousand Oaks, CA: SAGE Publications, 2011), 788-792.

19 Ussama Makdisi, "Reclaiming the Land of the Bible: Missionaries, Secularism, and Evangelical Modernity," The American Historical Review 102, no. 3 (1997): 680-713.; Ussama Samir Makdisi, Artillery of Heaven : American Missionaries and the Failed Conversion of the Middle East (Ithaca: Cornell University Press, 2008), 262. Makdisi is a prolific historian of USArab historical relations as Professor in Arabic Studies at Rice University.

20 Carla Eddé, L'USJ: Portrait d'Une Université (Beyrouth: Presses de l'Université Saint-Joseph, 2000), 159. Eddé's history of the USJ is an official history of the university. 
Adventurers of God and the Republic: Consuls and Missionaries in China (1844-1937)].21 France has a long history of using language and education for foreign policy purposes. ${ }^{22}$ The French Republic has had no scruples using Catholic missionary education to promote the French language. Foreign Minister Aristide Briand presented a particularly clear and elegant expression of this strategy in the Chambre des députés, where he explained the logic of Catholic French-language missionary education, later university studies in Paris and finally foreign representatives working French at the League of Nations in Geneva. ${ }^{23}$

Since the founding of the Université Saint-Joseph de Beyrouth in 1875, the Jesuit order, the French Republic and French business has worked together to promote common and separate interests. The university's medical school set up in 1883 was a branch of the University of Paris issuing French diplomas. In the early 1900s, the University of Lyon together with the Lyon Chamber of Commerce and Industry, representing important interests in Lebanese silk industry, sponsored faculties of engineering, political science/law. The faculties of the Université Saint-Joseph de Beyrouth were branches of the University of Paris and the University of Lyon issuing their ow French diplomas, but managed by the Jesuits, until the Lebanese civil war, when Université Saint-Joseph de Beyrouth took over the faculties itself and started issuing its own diplomas recognized in France. ${ }^{24}$ Interviews with French diplomats in Beirut emphasized the key position of the Université Saint-Joseph de Beyrouth for maintaining the status of French in Lebanon. A senior diplomat formulated the importance as the Université Saint-Joseph de Beyrouth as "the flag-ship of the Lebanese Francophonie without which the fleet of smaller vessels [institutions] would scatter."

The historical and other research, including my own, on these universities show the movements of information, ideas, talent and money through these universities between the USA and France and the Middle East and Asia. ${ }^{25}$ These movements are analyzed in this article with a focus on

21 Corinne de Ménonville, Les Aventuriers De Dieu Et De La République: Consuls Et Missionnaires En Chine (1844-1937) (Paris: Les Indes Savantes, 2007). De Ménonville's book on French consuls and missionaries in China is academic research in History.

22 Stanislav Sretenovic, "French Cultural Diplomacy in the Kingdom of Serbs, Croats and Slovenians in the 1920s," European Review of History 16, no. 1 (2009), 33-47.

23 Aristide Briand, "Speech/debate in Chambre Des Députés, 20 March 1929," Annales De La Chambre Des Députés (1929), 968-973.

24 Eddé, L'USJ: Portrait d'Une Université, 159

25 Bashshur, The Role of Two Western Universities in the National Life of Lebanon and the Middle East: A Comparative Study of the American University of Beirut and the University of Saint-Joseph; Lutz, China and the Christian Colleges 1859-1950; West, Yenching University and Sino-Western Relations, 1916-1952; Khalaf, The Economics of the American University of Beirut: A Study of a Private University in the Developing World, 99; Hanna, An American Mission: The Role of the American University of Beirut, 123; Ménonville, Les Aventuriers De Dieu Et De La République: Consuls Et Missionnaires En Chine (1844-1937); Makdisi, Artillery of Heaven : American Missionaries and the Failed Conversion of the Middle East, 262; Bays and Widmer, China's Christian Colleges: Cross-Cultural Connections, 1900-1950, 432; Anderson, The American University of Beirut: Arab Nationalism and Liberal Education, 254; Murphy, The American University in Cairo, 1919-1987, 288; Eddé, L'USJ: Portrait d'Une Université, 159; Dodge, The American University of Beirut; an Introduction to Beirut and the University, 117; 
transnational professional relations. These universities remain key academic institutions in the Middle East today. They continue to play central roles in Middle East-West intellectual, business, political and other socio-economic relations. These universities have been and continue to be bridges of information, talent and resources. Western science has been taught in the Middle East, while cultural, social and natural area knowledge has been created and shared in Western research environments. Western faculty and administrators have been recruited to the Middle East, while local talent has travelled to the USA and France for graduate studies and either settling there forming influential diasporas, returning to the Middle East or circulating between the West and the Middle East. These universities have been very successful raising American and French religious and secular philanthropic, corporate and government financial and political support for education, research, healthcare and social development in the Middle East, which I have described as "reverse soft power" ${ }^{26}$

In East Asia, missionary educators were active at the same time founding universities, which are also discussed in this article. American Protestant missionaries founded around 20 colleges, universities, medical schools and law schools in China, such as Yenching University, Canton Christian College, Saint John's University in Shanghai and Yale in China. Other Western states and groups also founded universities in China. French(-educated) Jesuits founded Université l'Aurore, which today is Fudan University, one of the most prominent universities in Shanghai and all of China. As with the American and French universities in the Middle East, the missionary universities in East Asia were "broadband" connections - in the sense of much information transmitted concurrently - between East Asian and Western society, with exchange of ideas, people and money. The universities in China played this broadband connection role until they were nationalized after the outbreak of the Korean War. ${ }^{27}$ The

Dodge, The American University of Beirut; a Brief History of the University and the Lands which it Serves, 127; Penrose, That they may have Life; the Story of the American University of Beirut, 1866-1941, 347; Munro, A Mutual Concern: The Story of the American University of Beirut, 198; Abou, L'USJ 125 Ans Après : Les Défis Et l'Espoir, 101-124; Abou, Les Libertés : Discours Annuels De Recteur De l'Université Saint-Joseph De 1996 à 2003, 201; Rasmus Gjedssø Bertelsen, Neema Noori and Jean-Marc Rickli, eds., Strategies of Knowledge Transfer for Economic Diversification in the Arab States of the Gulf (Berlin \& London: Gerlach Press, 2017), 230.; Bertelsen, The American University of Beirut: A Case for Studying Universities in International Politics, 133142; Bertelsen, American Missionary Universities in China and the Middle East and American Philanthropy: Interacting Soft Power of Transnational Actors, 113-127; Bertelsen, The University as a Transnational Actor with Transnational Power: American Missionary Universities in the Middle East and China, 624-627; Bertelsen, Private Foreign-Affiliated Universities, the State and Soft Power: The American University of Beirut and the American University in Cairo, 293-311; Bertelsen, The Effect of Public and Private Decisions on University Governance on the Transnational Relations of American-Associated Universities in the Middle East, 45-62

26 Bertelsen, Private Foreign-Affiliated Universities, the State and Soft Power: The American University of Beirut and the American University in Cairo, 293-311; Bertelsen, The Effect of Public and Private Decisions on University Governance on the Transnational Relations of American-Associated Universities in the Middle East, 45-62

27 Lutz, China and the Christian Colleges 1859-1950; Philip West, Yenching University and SinoWestern Relations, 1916-1952 (Cambridge, MA: Harvard University Press, 1976). 
nationalized universities in China continue to play such a bridging role. For instance, Fudan University has strong international relations to the USA and also the Nordic Countries as illustrated by its national Center for America Studies and Nordic Centre. ${ }^{28}$

American missionaries also founded a number of higher education institutions in Japan, such as Kwansei Gakuin University, Aoyama Gakuin University and Meiji Gakuin University. Catholics founded a number of institutions, most prominently the Jesuit Sophia University in Tokyo. The universities in Japan have succeeded to the extent that they have melded into Japanese society. ${ }^{29}$

Historians of transnational cultural and social relations between the West and the East are well aware of the long-term roles the universities here play in channeling knowledge, talent and resources between societies, which International Relations scholars are much less familiar with. There is an extensive historical research ${ }^{30}$ on these universities, which is the basis for my

28 "Nordic Centre," Nordic Centre, , accessed 08/09, 2018, http://www.nordiccentre.org.; "Center for American Studies, Fudan University," Fudan University, last modified nd, accessed 08/09, 2018, http://www.cas.fudan.edu.cn/index.en.php.

${ }^{29}$ This was my observation as Japan Society for the Promotion of Science postdoctoral fellow at United Nations University-Institute of Advanced Studies (Yokohama) and Tokyo Institute of Technology. In this connection, I gave two guest lectures at Meiji Gakuin University (one of the key American missionary legacy universities), and I asked a large auditorium of Meiji Gakuin University students, who a prominent sculpture on the campus depicted. None of the students knew it was of the American missionary, Reverend, Dr James Curtis Hepburn, who founded the university in 1863. Equally, I had several visits to Aoyama Gakuin University, another American missionary legacy university, which gave a similar impression of little awareness of the American Protestant missionary heritage of the university. The Jesuit Sophia University in Tokyo has a distinctive profile and identity as a cosmopolitan, Jesuit university, where one such aspect is recruiting Jesuits from abroad.

30 John Murchison Munro, A Mutual Concern: The Story of the American University of Beirut (Delmar, NY: Caravan Books, 1977), 198.; Faith M. Hanna, An American Mission: The Role of the American University of Beirut (Boston: Alphabet Press, 1979), 123.; Betty Signe Anderson, The American University of Beirut: Arab Nationalism and Liberal Education (Austin: University of Texas Press, 2011), 254.; Bayard Dodge, The American University of Beirut; a Brief History of the University and the Lands which it Serves (Beirut: Khayat's, 1958), 127.; Stephen Beasley Linnard Penrose, That they may have Life; the Story of the American University of Beirut, 18661941 (Beirut: American University of Beirut, 1970), 347.; Lawrence R. Murphy, The American University in Cairo, 1919-1987 (Cairo: American University in Cairo Press, 1987), 288.; Carla Eddé, L'USJ: Portrait D'Une Université (Beyrouth: Presses de l'Université Saint-Joseph, 2000), 159.; Peter Tze Ming Ng and others, Changing Paradigms of Christian Higher Education in China, 1888-1950 (New York: The Edwin Mellen Press, 2002), 237.; Jessie Gregory Lutz, China and the Christian Colleges 1859-1950 (New York: Cornell University Press, 1971).; Yihua Xu, "St John's University, Shanghai, as an Evangelising Agency," Studies in World Christianity 12, no. 1 (2006): 23-49.; Edward Yihua Xu, "Liberal Arts Education in English and Campus Culture at St. John's University," in China's Christian Colleges: Cross-Cultural Connections, 1900-1950, eds. Daniel H. Bays and Ellen Widmer (Stanford, CA: Stanford University Press, 2009), 107124. 
International Relations research into the universities as transnational actors. This historical research shows how the universities have long histories of being deeply engaged in moving information, ideas, talent and financial resources across borders. Still, universities have often been an overlooked category of transnational actors in International Relations research, which often ignores historical research. Fortunately, International Relations literature on the university as an actor in international politics is emerging. A good overview of young researchers working on the university as international actors is in the 2014 symposium on "Higher Education and World Politics" in PS Political Science \& Politics published by the American Political Science Association. ${ }^{31}$

There is an extensive historical literature on transnational educational relations. Although, this historical literature may refer to a concept as power or foreign policy, there is little if any engagement with International Relations theory, which points to the mutual benefits between History and International Relations in sharing data, theories and concepts. Paul A. Kramer's article on international students and US global power is an untapped treasure trove for International Relations and Political Psychology theoretical discussions. Kramer discusses the geopolitical grounds for the US Government and American universities recruiting international students and for American educators and missionaries to go abroad. ${ }^{32}$ But Kramer at no point draws on theory in International Relations on soft power or in Political Psychology on political socialization which could have structured the argument on the geopolitical significance of this talent mobility between the USA and the rest of the world.

Comparison is a key approach in Political Science, and my research seeks to compare transnational knowledge relations between American-Middle East/East Asia and FrenchMiddle East/East Asia and between historical cases and current developments in transnational higher education. The historical literature on the cases studied here does not compare between American transnational knowledge relations with the Middle East and East Asia or with France's relations with these regions. This lack of comparison is also seen elsewhere in key scholarship on transnational educational relations. One example of absence of comparison is Tamson Pietsch's study of British Imperial educational relations. She documents and analyzes the mobility of university professors within the British Empire without comparing with other empires. ${ }^{33}$

Stuart W. Leslie and Robert Kargon tell a clear history about science and technology educational relations between the MIT, India and Iran and between Stanford University and South Korea. These relations between the USA and India, Iran and South Korea during the Cold War are

\footnotetext{
${ }^{31}$ See the symposium in PS: Political Science \& Politics introduced by Isaac Kamola and Neema Noori, "Higher Education and World Politics," PS: Political Science \& Politics, no. July (2014): 599-603.

32 Paul A. Kramer, "Bernath Lecture: Is the World our Campus? International Students and U.S. Global Power in the Long Twentieth Century*," Diplomatic History 33, no. 5 (2009): 775806.

33 Tamson Pietsch, "Wandering Scholars? Academic Mobility and the British World, 18501940," Journal of Historical Geography 36 (2010): 377-387.; Tamson Pietsch, Empire of Scholars : Universities, Networks and the British Academic World, 1850-1939 (Manchester: Manchester University Press, 2013), 242.
} 
important cases in US foreign relations during the time, but Leslie and Kargon - like Kramer mentioned above - do not use International Relations and Political Science theories and concepts of soft and smart power to structure their research. ${ }^{34} \mathrm{~A}$ final example of not applying International Relations concepts to a rich historical material is the special issue of the Journal of Transatlantic Studies on "Diplomacy on Campus: The Political Dimensions of Academic Exchange in the North Atlantic." There is much valuable material for International Relations analysis and theoretical discussion in that research, which the historian authors do not themselves engage in. ${ }^{35}$

These longitudinal, comparative historical case studies contribute in a theoretically informed way to address the key question around the transnational soft power of such universities, and how this power interacts with the power of both Western states of origin and Eastern host states. The key to such transnational soft power is the strong transnational relations maintained by these universities with a range of academic, business, civil society and government actors in both the Eastern host society and the Western society of origin. ${ }^{36}$

An empirical contribution of my research is to bring together unconnected fields of study. In historical studies of Middle-East-American relations, the American missionary universities in the region are well researched. This research documents well their strong transnational relations with academia, business, civil society and government in both regions and connecting these actors, but without using or contributing to International Relations literature. ${ }^{37}$ These

34 Stuart W. Leslie and Robert Kargon, "Exporting MIT: Science, Technology, and Nation Building in India and Iran," Osiris 21, no. 1: Global Power Knowledge:Science and Technology in International Affairs (2006): 110-130.

35 Thomas Adam and Charlotte A. Lerg, "Special Issue: Diplomacy on Campus: The Political Dimensions of Academic Exchange in the North Atlantic," Journal of Transatlantic Studies 13, no. 4 (2015): 299-372.

36 Rasmus Gjedssø Bertelsen and Steffen Thybo Møller, The Soft Power of American Missionary Universities in China and of their Legacies: St. John's University, Yale-in-China and Yenching University (Copenhagen: Asia Research Centre, Copenhagen Business School,[2010b]); Bertelsen, Private Foreign-Affiliated Universities, the State and Soft Power: The American University of Beirut and the American University in Cairo, 293-311.; Bertelsen, The University as a Transnational Actor with Transnational Power: American Missionary Universities in the Middle East and China, 624-627.; Bertelsen, American Missionary Universities in China and the Middle East and American Philanthropy: Interacting Soft Power of Transnational Actors, 113127.; Bertelsen, The Political Context for Transnational Actor Soft Power: Classical American Overseas Missionary Universities and the State

37 Penrose, That they may have Life; the Story of the American University of Beirut, 1866-1941, 347.; Munro, A Mutual Concern: The Story of the American University of Beirut, 198.; Dodge, The American University of Beirut; a Brief History of the University and the Lands which it Serves, 127.; Hanna, An American Mission: The Role of the American University of Beirut, 123.; Anderson, The American University of Beirut: Arab Nationalism and Liberal Education, 254.; Murphy, The American University in Cairo, 1919-1987, 288. 
American universities have in recent years in the context of the War on Terror received policy attention for soft power aims to spread American liberal values in the Middle East. ${ }^{38}$

Since Munir Bashshur's 1964 University of Chicago doctoral dissertation in education comparing AUB and USJ,39 there has been no comparative study of the two Western flagship universities of Beirut. There have also not been comparative studies of American and French higher education in the wider Middle East or in East Asia. This absence is regrettable, since comparing the AUB and USJ or American and French transnational higher education and policies behind such education in the Middle East and in East Asia is illustrative of state and university relations and policies in the USA and France at different time periods. France as an old great power has used both private religious and public higher education for foreign policy purposes. The USA is a more recent great power in the Middle East and globally, and private religious American higher education was the driver of global engagement in the late 1800s and early 1900s, where the US Government only became involved during World War Two and in the $1950 s^{40}$

Scholars of Chinese-American history have devoted attention to the rich legacy of the American educational missionaries in China and the rich institutional legacy they built. This research also documents these universities as the broadband connections of their time between American and Chinese society in terms of channeling ideas, information, talent and money between the two societies. ${ }^{41}$ With excellent historical scholarship on the American universities in the Middle

38 John Waterbury, "Hate Your Policies, Love Your Institutions," Foreign Affairs 82 (2003): 5868.; John Waterbury, "A President's Beirut Diary," The Chronicle of Higher Education8 September, 2006.; Center for Strategic \& International Studies, Smart Power in the Obama Administration: The Role of International Education and Exchange, Smart Power in the Obama Administration: The Role of International Education and Exchange. 2009 Center for Strategic \& International Studies.; William A. Rugh, American Encounters with Arabs: The "Soft Power" of U.S. Public Diplomacy in the Middle East (Westport, CT: Praeger International Security, 2006), 211.

${ }^{39}$ Munir Antonios Bashshur, "The Role of Two Western Universities in the National Life of Lebanon and the Middle East: A Comparative Study of the American University of Beirut and the University of Saint-Joseph" (Doctor of Philosophy, University of Chicago), .

40 Bertelsen, The Effect of Public and Private Decisions on University Governance on the Transnational Relations of American-Associated Universities in the Middle East, 45-62; Bertelsen, Private Foreign-Affiliated Universities, the State and Soft Power: The American University of Beirut and the American University in Cairo, 293-311; Ménonville, Les Aventuriers De Dieu Et De La République: Consuls Et Missionnaires En Chine (1844-1937); Eddé, L'USJ: Portrait d'Une Université, 159; Murphy, The American University in Cairo, 1919-1987, 288; Dodge, The American University of Beirut; a Brief History of the University and the Lands which it Serves, 127

41 Lutz, China and the Christian Colleges 1859-1950; West, Yenching University and SinoWestern Relations, 1916-1952; Xu, St John's University, Shanghai, as an Evangelising Agency, 2349.; Mary Brown Bullock, The Oil Prince's Legacy: Rockefeller philanthropy in China (Washington, DC; Stanford, CA: Woodrow Wilson Center Press; Stanford University Press, 2011), 242.; Dong Wang, "From Lingnan to Pomona: Charles K. Edmunds and His Chinese American Career," in China's Christian Colleges: Cross-Cultural Connections, 1900-1950, eds. 
East on one hand and equally on the American universities in China on the other hand, it is unfortunate, that there has been no comparison of the American missionary universities in the Middle East and China. This lack of comparison is despite their common origins and their strong impact on America's relations with these regions.

Yet another missing comparison is between the historical American missionary universities in the Middle East and the new transnational private universities, which the old universities often inspire. The highly respected American missionary universities in the Middle East, especially AUB and AUC, have strongly inspired the wave of new transnational private universities in the Middle East, which often bear names, such as American University in Dubai, of Kuwait, of Sharjah, etc. ${ }^{42}$ However, in the education studies literature on the many new transnational universities in the Middle East, ${ }^{43}$ there is little comparison with the missionary institutions, although such comparisons could yield insights on transnational relations, academic quality and the range of studies and disciplines. ${ }^{44}$ My research bridges these gaps to discuss the question of transnational professional skills and relations, which is the topic of this special issue.

The history of American and French missionary universities is valuable for looking at recent developments in transnational professional education. In recent decades, societies throughout the Global South have seen a great expansion of private, often for-profit, higher education. This is also very much the case in the Middle East, whose educational expansion parallels that of the Global South, making it particularly relevant for this study. This expansion of private higher

Daniel H. Bays and Ellen Widmer (Stanford, CA: Stanford University Press, 2009), 173-188.; Dong Wang, Managing God's Higher Learning: U.S.-China Cultural Encounter and Canton Christian College (Lingnan University) 1888-1952 (Lanham, MD: Lexington Books, 2007), 211.; $\mathrm{Xu}$, Liberal Arts Education in English and Campus Culture at St. John's University, 107-124.; Paul Daniel Waite and Peichi Tung Waite, "China's Christian Colleges and the Founding of the Harvard-Yenching Institute," in China's Christian Colleges: Cross-Cultural Connections, 19001950, eds. Daniel H. Bays and Ellen Widmer (Stanford, CA: Stanford University Press, 2009), 241-266.

42 Interviews, Interviews in Beirut, Cairo, Cambridge, MA, Medford, MA, New York and Washington, $D C$

43 Michael Barber, Mona Mourshed and Fenton Whelan, "Improving Education in the Gulf," The McKinsey Quarterly, no. Special edition: Reappraising the Gulf States (2007): 39-47.; Christopher Davidson and Peter Mackenzie Smith, eds., Higher Education in the Gulf States: Shaping Economies, Politics and Cultures (London: Al-Saqi Books in association with The London Middle East Institute at SOAS, 2008), 192.; Alisa Rubin Peled, Adaptation, Ideals, Vision and Deals: The Rise of American Higher Education in the Arab World (Cambridge, MA: Harvard University Press, 2012):; World Bank, The Road Not Travelled: Education Reform in the Middle East (Washington, DC: ,[2008]).

44 Bertelsen, Public Policy, University Governance and Transnational Linkages: AmericanAssociated Universities in the Middle East; Bertelsen, Private Higher Education in the GCC: Best Practices in Governance, Quality Assurance and Funding, 1-8.; Bertelsen, American- and FrenchAffiliated Universities in the Middle East as 'Information and Resource Bridges' to the West, 126.; Bertelsen, The Effect of Public and Private Decisions on University Governance on the Transnational Relations of American-Associated Universities in the Middle East, 45-62. 
education is driven by demographics of large youth populations aspiring for tertiary education based on previous investments in primary and secondary education and on highly competitive labor-markets, where higher education is seen as the panacea to gain professional employment. Governments throughout Africa, Asia and Latin America have been unable or unwilling to satisfy this demand for tertiary education in public institutions. Therefore, these governments have invited the private sector to respond to this demand, which is financed by investors and ultimately students and their families. There are serious issues of governance, quality assurance and socially equitable access to education from this expansion of private higher education. Much of this private higher education in the Global South is transnational in nature, with widely varying partnerships, mainly with Western institutions, so that quality-assurance, capacity-building and academic credibility are established and realized. ${ }^{45}$

Comparing the universities from around 1900 that have missionary roots with the recent universities from the mid-1990s shows strong variation in the quality of transnational relations, and suggests that this variation is explained by the ownership and governance models of these universities. The missionary, who remain non-profit, and some new universities can focus on academic excellence and therefore have strong academic credibility among stakeholders in East and West. In contrast, new for-profit universities are forced to focus on profitability, distracted from focusing on academic excellence and so have weaker credibility. This development from non-profit religious or public higher education to for-profit higher education is a significant development in developing countries and emerging markets, as well as in the USA, but not Europe. ${ }^{46}$

\section{The History of Transnational Universities and Intellectuals forming Transnational Professionals}

The historical transnational American and French missionary universities studied in this research are the products of transnational elites. These universities played and continue to play a central role in producing, reproducing, selecting and socializing transnational elites. The American universities with missionary roots were the product of the collaboration between American missionaries with exceptional transnational insight and experience and "the learned,

45 Salma A. Al-Lamki, "The Development of Private Higher Education in the Sultanate of Oman: Perception and Analysis," International Journal of Private Education 1 (2006): 54-77.; Philip G. Altbach and Daniel Levy, eds., Private Higher Education: A Global Revolution (Rotterdam, Taipei: Sense Publishers, 2005).; Philip G. Altbach, ed., Private Prometheus : Private Higher Education and Development in the 21st Century, Vol. 77 (Westport, Conn.: Greenwood Press, 1999), 237.

46 Altbach, Private Prometheus : Private Higher Education and Development in the 21st Century, 237; Altbach and Levy, Private Higher Education: A Global Revolution Bertelsen, Public Policy, University Governance and Transnational Linkages: American-Associated Universities in the Middle East; Bertelsen, Private Higher Education in the GCC: Best Practices in Governance, Quality Assurance and Funding, 1-8.; Bertelsen, American- and French-Affiliated Universities in the Middle East as 'Information and Resource Bridges' to the West, 1-26.; Bertelsen, The Effect of Public and Private Decisions on University Governance on the Transnational Relations of American-Associated Universities in the Middle East, 45-62. 
wealthy and pious" of American centers of industry. ${ }^{47}$ In the mid-1800s, one of the effects of the religious revival of American society was that missionaries went off to East Asia and the Middle East to preach American Protestantism. However, this direct proselytizing had very little success in terms of conversion. This lack of success led to the next generation of missionaries, who became very successful transnational intellectuals and educational professionals as founders of universities which continue to influence American and overseas societies. The next generation of missionaries, in the late 1800s and early 1900s, were sometimes children of the first generation and understood the futility of straightforward proselytizing. These individuals had grown up overseas, spoke local languages fluently and had been sent back to the United States to leading Protestant American colleges for education. Two influential cases were Dr. Charles A. Watson, founder of the AUC, born in Egypt to missionary parents and educated at Lawrenceville and Princeton, and John Leighton Stuart, founding president of Yenching University, born in China and educated at Hampden Sydney College and Union Theological Seminary. This generation of missionaries understood that the best way forward for mission was through educational institutions that attracted local youth and shaped future leaders. These educational entrepreneurs behind the highly successful American universities in the Middle East and East Asia were supported by missionary societies in the USA as mentioned above. We see the central role of commercial, intellectual and professional elites for building transnational relations that would have a long-term impact. 48

Another strong current of transnational missionary higher education was Jesuit. The Jesuits of the Levant had, in the 1800s, been placed under the Jesuit Province of Lyon and the linguistic and intellectual ties from the Levant were therefore predominantly with France, as reflected

47 Lawrence R. Murphy, The American University in Cairo, 1919-1987 (Cairo: American University in Cairo Press, 1987), 288. p. 1.

48 This very short overview of American missionary university history reflects the historical literature on these institutions. This research is academic historical research. The exceptions are perhaps Bayard Dodge and Stephen Penrose's histories of the American University of Beirut. Penrose succeeded Dodge as President of the American University of Beirut. Dodge was an Islamic scholar and historian of Arabic education, and Penrose a philosopher: Dodge, The American University of Beirut; a Brief History of the University and the Lands which it Serves, 127.; Penrose, That they may have Life; the Story of the American University of Beirut, 1866-1941, 347.; Munro, A Mutual Concern: The Story of the American University of Beirut, 198.; Hanna, An American Mission: The Role of the American University of Beirut, 123.; Anderson, The American University of Beirut: Arab Nationalism and Liberal Education, 254.; Ussama Samir Makdisi, Artillery of Heaven : American Missionaries and the Failed Conversion of the Middle East (Ithaca: Cornell University Press, 2008), 262.; Lutz, China and the Christian Colleges 1859-1950; Waite and Waite, China's Christian Colleges and the Founding of the Harvard-Yenching Institute, 241-266.; West, Yenching University and Sino-Western Relations, 1916-1952; Ng and others, Changing Paradigms of Christian Higher Education in China, 18881950, 237.; Xu, Liberal Arts Education in English and Campus Culture at St. John's University, 107-124.; Xu, St John's University, Shanghai, as an Evangelising Agency, 23-49.; Wang, Managing God's Higher Learning: U.S.-China Cultural Encounter and Canton Christian College (Lingnan University) 1888-1952, 211.; Wang, From Lingnan to Pomona: Charles K. Edmunds and His Chinese American Career, 173-188. Kramer, Bernath Lecture: Is the World our Campus? International Students and U.S. Global Power in the Long Twentieth Century*, 775-806. 
ever since in the USJ. Université l'Aurore in Shanghai was founded by the French-educated Chinese Jesuit Joseph Ma Xiangbo in 1903 and nationalized as Fudan University in 1952. European Jesuits founded Sophia University in 1912, but today Jesuits from East Asia and the Global South have an increasingly prominent position. ${ }^{49}$

These Protestant and Jesuit transnational academic entrepreneurs created institutions, which have been important for creating classes and communities of transnational intellectuals and professionals spanning the East and the West. As mentioned, the original aim of the American Protestant missionary universities was proselytizing, but that turned out to be very unsuccessful as the previous generation's preaching on streets had been. USJ had a Maronite Catholic community to cater to, while there was naturally no local Protestant community. Young people in the Middle East did seek education at the American Protestant universities in Beirut and Cairo because of educational excellence and the improved life chances that education offered, which directly addresses the topic of this special issue of transnational professional relations. The students were clearly not attracted by the Protestant missionary message, since they from early on protested the obligatory Protestant religious teaching and services. 50

Likewise, in China, the American missionary universities aimed to attract Chinese youth to be trained as Church ministers. Parallel to the Middle East, American Protestantism met little interest among the local population. So, the American Protestant universities in China had so little success in attracting Chinese youth to theology education, that the universities had to pay all costs of the students, including travel to the schools. However, this changed when Chinese families in commercial industries, who lived and work in the treaty ports, realized that their sons could gain an English-language education of high value that was advantageous for working in international trading houses in the treaty ports in China. By changing their curriculum to secular, professionally-oriented topics, American missionary universities in China began attracting sons of wealthy Chinese trading families who could pay the high fees. ${ }^{51}$

49 UNESCO Assemblée générale au Liban, Université Saint-Joseph De Beyrouth (Beyrouth: UNESCO, 1948).; Eddé, L'USJ: Portrait D'Une Université, 159.; Sophia University, "Sophia University," Sophia University, http://www.sophia.ac.jp/eng/e top Ménonville, Les Aventuriers De Dieu Et De La République: Consuls Et Missionnaires En Chine (1844-1937) 50 Bertelsen and Møller, The Soft Power of American Missionary Universities in China and of their Legacies: St. John's University, Yale-in-China and Yenching University, 1-39.; Bertelsen, Private Foreign-Affiliated Universities, the State and Soft Power: The American University of Beirut and the American University in Cairo, 293-311.; Bertelsen, American Missionary Universities in China and the Middle East and American Philanthropy: Interacting Soft Power of Transnational Actors, 113-127.; Bertelsen, The University as a Transnational Actor with Transnational Power: American Missionary Universities in the Middle East and China, 624-627. 51 Lutz, China and the Christian Colleges 1859-1950; West, Yenching University and SinoWestern Relations, 1916-1952; Waite and Waite, China's Christian Colleges and the Founding of the Harvard-Yenching Institute, 241-266.; Ng and others, Changing Paradigms of Christian Higher Education in China, 1888-1950, 237.; Xu, Liberal Arts Education in English and Campus Culture at St. John's University, 107-124.; Xu, St John's University, Shanghai, as an Evangelising Agency, 23-49.; Wang, Managing God's Higher Learning: U.S.-China Cultural Encounter and 
The original American and French missionary universities in the Middle East continue to base their success on high quality education. The Americans introduced liberal arts. Both Americans and French introduced professional education to the Middle East and East Asia in areas, such as engineering, law, medicine, dentistry and commerce, by establishing medical schools, engineering faculties, business schools, law schools. These professional schools structured local professional life. For instance, the law school of the USJ was the only law school of Lebanon until the establishment of the national Lebanese University in 1951, which meant a strong influence from French legal tradition and scholarship. The historical universities in the Middle East and East Asia, therefore, introduced possibilities for gaining skills for professional work in commerce or in professions, such as engineering, law, medicine, the Church ministry (where recruiting was unsuccessful because of little local interest in proselytizing and conversion to Protestantism as explained above both concerning the Middle East and East Asia), etc. The historians of these universities show how these universities, together with the integration of these societies into Western-led capitalism, made it possible for new groups, who had the means and willingness to send their sons to these schools, to gain the skills for taking part in an international capitalist economy and to enter into new professions in the urban environments of Beirut, Cairo, Beijing, Shanghai, Tokyo, and beyond. The American universities in both the Middle East and East Asia emphasized their liberal arts identity and creating well-rounded "men" for professional work in agriculture, commerce, engineering, health sciences, policy, etc. Their self-image and mission was clearly to build character and shape men for taking part in a modern, Western, professional lifestyle and civic life. Betty S. Anderson has brought this strong ethos for the AUB clearly in her research. The Syrian Protestant College was opened specifically with a college and a medical school to train Western doctors; this was also the case for several of the American universities in China, which also included law schools, specifically destined for training local men for professional services. ${ }^{52}$ In their time, these universities were targeted for male students and gradually opened up to women students. Missionary education in parallel opened up possibilities for women, where the Lebanese American University traces its roots to the American School for Girls opened in 1835 by American Presbyterian missionaries. This school started to offer college education for women in the 1920 s. $^{53}$

Canton Christian College (Lingnan University) 1888-1952, 211.; Wang, From Lingnan to Pomona: Charles K. Edmunds and His Chinese American Career, 173-188.

52 Dodge, The American University of Beirut; a Brief History of the University and the Lands which it Serves, 127.; Eddé, L'USJ: Portrait D'Une Université, 159.; Lutz, China and the Christian Colleges 1859-1950; Munro, A Mutual Concern: The Story of the American University of Beirut, 198.; Murphy, The American University in Cairo, 1919-1987, 288.; Anderson, The American University of Beirut: Arab Nationalism and Liberal Education, 254.; Ng and others, Changing Paradigms of Christian Higher Education in China, 1888-1950, 237.; Penrose, That they may have Life; the Story of the American University of Beirut, 1866-1941, 347.; UNESCO Assemblée générale au Liban, Université Saint-Joseph De Beyrouth; West, Yenching University and SinoWestern Relations, 1916-1952; Xu, Liberal Arts Education in English and Campus Culture at St. John's University, 107-124.; Interviews, Interviews in Beirut, Cairo, Cambridge, MA, Medford, $M A$, New York and Washington, DC

53 "History," Lebanese American University, last modified nd, accessed 08/09, 2018, http://www.lau.edu.lb/about/history/. 
In Beirut, the Jesuits quickly responded to the American Protestant challenge of the Syrian Protestant College in 1866 and opened the USJ in Beirut in 1875. The USJ would be the basis of strong transnational professional relations between the Levant, the wider Middle East and France, which continue today. France has a long history of using French-language education abroad as a foreign policy tool to socialize foreign elites. The strategic value of USJ as a leading French-speaking university in the Levant has been clear in the interactions of the French state and USJ from the earliest years. They were clear during the Mandate period in the interwar years and during the after-war years when Beirut was the Paris of the Middle East, and this value was emphasized to me by a senior French diplomat at the French embassy in Beirut in August 2008: "The USJ is the flagship of the Lebanese Francophonie without which the smaller vessels of the fleet would scatter." So, the Jesuits and the French Republic quickly joined forces in their individual pursuits of transnational soft and smart power through education in the Levant. The marked difference to the USA at the time was how strategically the French Republic used Francophone Jesuit education for foreign policy purposes in collaboration with French universities and French business. The USA was dissociated from the private initiatives of the American Protestant educational missionaries until after the Second World War. In 1883, the French Medical School in Beirut opened as a partnership between the Jesuits and the French Republic. The school was sponsored financially and academically by the French Republic, supplying professors and issuing French diplomas from the University of Paris. In the first decade of the 1900s, business interests in Lebanese silk from Lyon initiated similar collaboration with USJ with the clear purpose of training French-speaking and Frenchorientated Lebanese human capital in engineering, administration and law. Therefore, the Chamber of Commerce of Lyon sponsored the university financially, and the University of Lyon academically sponsored schools of engineering and law and political science at USJ. This close collaboration between USJ and France, with the University of Paris sponsoring the faculty of medicine and the University of Lyon sponsoring the other faculties and issuing public French degrees, continued till the late 1970s during the Lebanese Civil War. Then the USJ took over the faculties as its own and issued its own degrees, although these degrees were still recognized by France. USJ, with its European academic tradition of education, focused on a profession (as opposed to the American liberal arts tradition) and has clearly contributed to creating FrancoArab professional classes in Lebanon and in other areas of the Middle East. ${ }^{54}$

The Franco-Lebanese transnational professional relations in law, government and engineering based on the partnership between the Chamber of Commerce of Lyon, University of Lyon and USJ have influenced Lebanese society deeply. Due to this partnership, USJ had the first and only law faculty in Lebanon until the foundation of the Lebanese University including a law faculty in the early 1950s. It is quite remarkable to have an independent state, which does not have a law faculty in a national university operating in the national language (Arabic). Therefore, USJ had significant influence training the legal profession and judges in Lebanon and was a conduit of French legal tradition into Lebanese law. The law faculty of USJ has a high reputation throughout the Middle East. When Dubai decided to establish a law school, it turned to USJ, which opened the Université Saint Joseph Law School Dubai in 2008. It is a remarkable testimony to the prestige of USJ, that a former British trucial, Muslim state should turn to a

54 Eddé, L'USJ: Portrait D'Une Université, 159.; Interviews, Interviews in Beirut, Cairo, Cambridge, MA, Medford, MA, New York and Washington, DC; UNESCO Assemblée générale au Liban, Université Saint-Joseph De Beyrouth 
Francophone, Jesuit university to establish a college of law. Sciences Po Beyrouth was the political science school at USJ, and has been a civil servant school, as is the tradition of political science in France and Continental Europe. As such, Sciences Po Beyrouth has, from early on, played a central role in forming and shaping a class of professional civil servants in Lebanon. The early engineering education at USJ sponsored by the University of Lyon and the partnership with the French state and French business, trained the first engineers for public works and private companies in Lebanon. ${ }^{55}$ The French Republic continues to be highly attentive to the importance of USJ to French transnational soft power in the Levant as mentioned above. The USJ is as mentioned above the "flag-ship of the Lebanese Francophonie" according to senior French diplomats in Beirut. The Strategic council of the university illustrated how it is a node of Francophone-Levantine elite networks across academia, business, government. ${ }^{56}$

When we look at the classical American and French universities in the Middle East today, it is clear that they continue to educate professional elites in academia, business, commerce, engineering, law, politics and policy. They are the most prestigious academic institutions in the Middle East. They are selective, and they often train future elites. ${ }^{57}$ For the American universities, this takes place in a combination of liberal arts education and professional graduate schools, which destine graduates to enter professions, such as medicine, pharmacy, business, engineering or public policy. AUB and AUC have founded high-profile professional graduate schools, such as the Suliman S. Olayan School of Business, the Rafic Hariri School of Nursing, Faculty of Agriculture and Food Sciences, Faculty of Health Sciences, Faculty of Medicine, Faculty of Engineering and Architecture at the AUB, and Graduate School of Education, the School of Business, School of Global Affairs and Public Policy, School of Sciences and Engineering, and the School of Humanities and Social Sciences at AUC. USJ continues its Franco-European tradition of professional education in health sciences, law and political science, engineering and more, supplying Lebanon with professionals with a transnational Franco-Arab background.58

\section{Comparing Missionary Universities and New Transnational Universities: Ensuring Access to Transnational Professionalism}

Transnational private higher education plays a larger role in the Global South today than in the late 1800s and 1900s, when American and European missionaries founded universities in the Middle East and East Asia. The historical American and French universities have not been compared with the new institutions (as History and International Relations had not dialogued

55 Eddé, L'USJ: Portrait D'Une Université, 159.; UNESCO Assemblée générale au Liban, Université Saint-Joseph De Beyrouth

56 "Conseil Stratégique [Strategic Council]," Université Saint-Joseph, last modified nd, accessed 08/09, 2018, https://www.usj.edu.lb/decouvrir/conseilsdeta.htm?code=221.

57 Waterbury, Hate Your Policies, Love Your Institutions, 58-68.; United States Department of State, "MEPI Tomorrow's Leaders Scholarship Program," United States Department of State, http://mepi.state.gov/opportunities/mepi-exchange-programs/tomorrows-leaders.html (accessed 02/28, 2015).

${ }^{58}$ For overview, see http://www.aub.edu.lb/main/Pages/index.aspx

http://new.aucegypt.edu and http://www.usj.edu.lb. 
concerning the historical institutions). There are both research and policy lessons to be learned from this comparison, which will here focus on education for professions in the Middle East.

The world changed profoundly between the late 1800s and early 1900s when the American and French universities in the Middle East and East Asia were founded and the 1990s and onwards when private higher education swept across the Global South. The former mandate of Lebanon, the protectorate of Egypt and the Gulf trucial states have gained independence. Today, Western private education operate in these countries on the conditions of sovereign, independent states, and not in colonized societies. Gulf states have gained enormous wealth through oil and gas. China has gone through a liberal and a communist revolution and is reclaiming its historical relative position in the world economy. The USA realized its hegemonic role and responsibility and replaced European great powers dominating the international system. What remains stable is the great importance and influence of Western-inspired and affiliated higher education around the world, where American- and French-affiliated higher education remains highly influential depending on the colonial language heritage of the region.

The new American- and European-associated private universities in the Middle East established since the mid-1990s continue this tradition of contributing to the creating of professional classes in the region, with an even greater focus on professional education. When comparing the historical with the new universities, what stands out is that transnational relations of the historical universities with academia, business, civil society and government in the West, are stronger than many of the new universities. Some of the new universities have strong transnational professional relations dependent on university governance structure. Strong transnational relations are found among the well-funded branch campuses of prominent Western universities, such as Education City in Qatar with Virginia Commonwealth University, Carnegie-Mellon University, Texas A\&M University, Georgetown University, Weill-Cornell Medical College and Northwestern University as well as HEC of Paris and University College London also in Qatar or Université Paris Sorbonne Abu Dhabi or New York University Abu Dhabi. Some local institutions as American University of Sharjah or the Petroleum Institute also have strong transnational relations. The large group of seemingly for-profit institutions have weaker and less prominent transnational relations. ${ }^{59}$

The Gulf states went through enormous societal changes and rapid development with the discovery of oil and gas, but it also made these countries extremely dependent on oil and gas rents and outside labour. There is a strong political desire in these states to diversify economies from oil- and gas-based to much more knowledge-based. ${ }^{60}$ The new universities are central institutions in these policies to transform oil- and gas-based economies into knowledge-based economies, with much greater labour market participation by locals, as reflected in Emiratization and Qatarization policies, to name a few. In the most oil- and gas-rich countries, such as Abu Dhabi or Qatar, very well-funded private universities, branch campuses of

59 Bertelsen, The Effect of Public and Private Decisions on University Governance on the Transnational Relations of American-Associated Universities in the Middle East, 45-62.; Bertelsen, Public Policy, University Governance and Transnational Linkages: AmericanAssociated Universities in the Middle East 60 Bertelsen, Noori and Rickli, Strategies of Knowledge Transfer for Economic Diversification in the Arab States of the Gulf, 230 
prominent Western universities or local institutions, are about creating local professional classes and professional economies with world-class skills, knowledge and education. The investments in attracting prominent Western universities to ensure academic quality and very strong, transnational academic relations (and transnational business, civil society and governmental relations to less extent) are probably the best chance these societies have at creating local, professional classes with strong global skills, credibility and networks in the shortest possible time. ${ }^{61}$

The expansion of private, for-profit higher education throughout the Global South focuses on the dreams of youth and their families of becoming professionals and entering professional classes in often extremely tight labor markets for youth. This is also the case in the Middle East, with its very young population and large problems of creating employment opportunities for youth and integrating youth into the economy. This is the case in the relatively poorer Oman, which relies on private for-profit education; Dubai, which has chosen a strategy around forprofit education; or even Kuwait, which also seems to promote private, for-profit transnational education. In these cases, the transnational academic partners in the West are much less prominent and the transnational academic, business, civil society and government ties are much weaker than for the well-funded, non-profit institutions mentioned above. Young people graduating from private, for-profit institutions will have a quite different starting point for breaking into global professional classes than those of their counterparts from the historical or new non-profit universities above. ${ }^{62}$

Looking at the Greater Middle East region as a whole, there is a significant post-colonial pathdependency in transnational, private higher education between the Anglophone and the Francophone Middle East. There are clear colonial linguistic legacies in education, which basically mean that the Anglophone Middle East is open for native English-speaking and other countries as Germany. On the contrary, France is all-dominant in the Maghreb and strongly represented in Lebanon. There is a minuscule Belgian presence in the Maghreb. Non-native French-speaking countries clearly do not have the language resources to compete in French with French institutions. This is the case in Morocco, where private institutions offer hundreds of Franco-Moroccan double-degree Masters degrees. The Anglophone Middle East has a great plurality of American, British, Canadian, European, Australian and also French-language institutions. There are in Gulf countries, but also in Egypt and Jordan, private universities with close ties to European public universities, such as the British University in Egypt, Université Française de l'Egypte or the German University in Cairo, offering degrees validated by public European universities. ${ }^{63}$

61 Barber, Mourshed and Whelan, Improving Education in the Gulf, 39-47.; World Bank, The Road Not Travelled: Education Reform in the Middle East; Davidson and Smith, Higher Education in the Gulf States: Shaping Economies, Politics and Cultures, 192. 62 Al-Lamki, The Development of Private Higher Education in the Sultanate of Oman: Perception and Analysis, 54-77.; World Bank, The Road Not Travelled: Education Reform in the Middle East; Davidson and Smith, Higher Education in the Gulf States: Shaping Economies, Politics and Cultures, 192.; Barber, Mourshed and Whelan, Improving Education in the Gulf, 39-47.

63 Office Méditerranéen de la Jeunesse, "Catalogue De Formation De Niveau Master 2 Et Doctorat Labellisées OMJ," Office Méditerranéen de la Jeunesse, http://catalogue.mediterraneanofficeforyouth.com (accessed 12/03, 2014). 
Again, it is useful to take the longer historical look and compare the historical American and French universities in the Middle East (and East Asia) to the new private, transnational universities in the Middle East. The new universities are representative of the wave of private higher education in the Global South. It is useful to compare the range of topics offered by the historical universities and the new universities. The historical universities were and remain well-rounded universities, offering degrees across the entire spectrum of humanities, social sciences, law, business, natural sciences, health sciences and technology, which is based on research in this range of disciplines. The American universities have emphasized and continued to emphasize liberal arts, although the families of students have sought professional competencies that could also ensure the professional futures of their children. As such, the classical universities in these regions offer their graduates broad degrees based on researchbased teaching. These are degrees, which were and still remain internationally highly respected. The new well-funded, non-profit transnational higher education in the Middle East is also able to offer such opportunities. ${ }^{64}$

In comparison, it is clear that the range of education at many of the new universities is much more limited and limited mainly to business, IT and softer engineering skills degrees, which are not generally research-based. The broad range of disciplines with the "breadless" humanities or the expensive natural and health sciences is generally absent at these new universities. Youth enrolled at these new institutions may get what appears to be very "professional" degrees, but they will face much greater challenges fulfilling their dreams of entering into professional classes with degrees that are narrower in scope, involve less critical thinking and have weaker and less prominent transnational ties than those of the historical universities. Societies in the Middle East and the broader Global South rely on such "professional", narrow, for-profit private higher education. These societies do not reap the benefits that research-based and broad universities with stronger critical thinking skills provide for creating truly professional, globally connected knowledge-based economies. ${ }^{65}$

\section{Conclusion: Combining History and International Relations on Transnational Universities and Professional Relations for Policy Lessons in the Global North and South}

This article illustrates the research value of combining rich historical research on American and French missionary universities in the Middle East and East Asia and International Relations theories and concepts on transnational relations. History gives empirical depth in terms of cases and longer timelines to International Relations, which as a sub-discipline of Political Science, is prone to "presentism" of shallow historical depth and mistakenly claiming that

\footnotetext{
${ }^{64}$ For overview of areas of teaching and research in these universities, see http://www.usj.edu.lb, http://new.aucegypt.edu, http://www.aub.edu.lb/main/Pages/index.aspx, http://nyuad.nyu.edu/en/, http://www.qf.org.qa http://www.sorbonne.ae http://www.aus.edu, http://www.pi.ac.ae/index.php. ${ }^{65}$ See, for instance, many degrees listed by the Office Méditerranéen de la Jeunesse, Ibid.
} 
phenomena can be new. In return, International Relations (and Political Science, Political Psychology and other Social Sciences) can contribute theories and concepts to structure rich historical material and comparisons.

The American and French missionary universities have contributed to transnational professional relations between the USA, France, the Middle East and East Asia. The founders of these universities were remarkable transnational intellectuals and educational professionals. Training Middle Easterners and East Asians for Western professional life has been an aim of these universities from the start. The American Protestant missionary universities are part of the American liberal arts tradition and sought and seek to train "men" according to the liberal arts ethos for professional life in business or through graduate schools in professions as medicine, etc. The French Jesuit universities reflect French and European professional or discipline-based university education, where students from the outset study a profession as medicine, law or engineering or a discipline as political science or economics. In any case, such education prepares directly for Western-style professional life.

An important contextual factor behind these universities building transnational professional networks and training professionals has been their strong transnational connections with academia, business, civil society and government in the USA, France, the Middle East and East Asia. The American Protestant and French Catholic missionary universities in this article show the value that academically excellent and all-encompassing universities with strong transnational relations to academia, business, civil society and government have for societies in the Global South. These qualities are important so that these nations can build knowledgebased societies and economies and that their citizens may enjoy the opportunities and benefits of professional work.

Comparison with many of the new transnational private universities in the Middle East and other developing countries and emerging markets reveals the much more applied and "professional" focus these universities apparently focused on immediate employability. These degrees are often in business administration, IT and softer (not requiring expensive research and teaching facilities) engineering topics. The liberal arts tradition, critical thinking and research-based education is absent. These new private universities often have comparatively much weaker transnational relations with academia, business and government in the West than the historical universities. The for-profit governance model of the new universities undermines their academic credibility. All in all, these aspects threaten the professional prospects of individual young people in the Middle East and other developing countries and emerging markets, who together with their families are desperate for such opportunities of a professional working life. At the macro-level, the disciplinary narrowness and research weakness of this new private higher education threatens the development of innovative, knowledge-based economies and societies.

Historical and International Relations scholarship can provide important insights for policy questions today. Comparing historical and new universities for their strengths in transnational relations, in research and in the range of educational opportunities, suggests policy implications both in the Global North and the Global South. The Global South should do what is possible to promote such higher education, promoting philanthropy and endowments, for instance, through taxation policy. However, many societies in the Global South are very hard- 
pressed to find the resources for philanthropic higher education and must turn to private investors seeking a return on their investment. In return, private, public and civil society actors in the Global North must acknowledge this challenge of private, higher education in the Global South and seek partnerships that support students and faculty, not investors. Such policies can give more people in the Global South transnational professional skills and the life chances they bring.

\section{Bibliography}

Abou, Sélim. Les Libertés : Discours Annuels De Recteur De l'Université Saint-Joseph De 1996 à 2003. Beyrouth: Presses de l'Université Saint-Joseph, 2003.

___. "L'USJ 125 Ans Après : Les Défis Et l'Espoir." In Les Libertés : Discours Annuels De Recteur De l'Université Saint-Joseph De 1996 à 2003, edited by Abou, Sélim, 101-124.

Beyrouth: Presses de l'Université Saint-Joseph, 2000.

Adler, Emanuel and Peter M. Haas. "Conclusion: Epistemic Communities, World Order, and the Creation of a Reflective Research Program." International Organization 46, no. 1, Knowledge, Power, and International Policy Coordination (Winter) (1992): 367-390.

Altbach, Philip G. and Daniel Levy, eds. Private Higher Education: A Global Revolution. Rotterdam, Taipei: Sense Publishers, 2005.

Altbach, Philip G., ed. Private Prometheus : Private Higher Education and Development in the 21st Century. Contributions to the Study of Education. Vol. 77. Westport, Conn.: Greenwood Press, 1999.

Anderson, Betty Signe. The American University of Beirut: Arab Nationalism and Liberal Education. Austin: University of Texas Press, 2011.

Bashshur, Munir Antonios. "The Role of Two Western Universities in the National Life of Lebanon and the Middle East: A Comparative Study of the American University of Beirut and the University of Saint-Joseph." Doctor of Philosophy, University of Chicago, 1964.

Bays, Daniel H. and Ellen Widmer, eds. China's Christian Colleges: Cross-Cultural Connections, 1900-1950. Stanford: Stanford University Press, 2009.

Bertelsen, Rasmus Gjedssø. "American Missionary Universities in China and the Middle East and American Philanthropy: Interacting Soft Power of Transnational Actors." Global Society 28, no. 1 (Special Issue: American Philanthropy and the Hard, Smart and Soft Power of the United States) (2014): 113-127.

- _- "The American University of Beirut: A Case for Studying Universities in International Politics." In One Hundred and Fifty, edited by El Cheikh, Nadia Maria, Lina Choueiri and Bilal Orfali, 133-142. Beirut: AUB Press, 2016.

- - - "The Effect of Public and Private Decisions on University Governance on the Transnational Relations of American-Associated Universities in the Middle East." Revue Des Mondes Musulmans Et De La Méditerannée 131, no. 1 (2012): 45-62.

_-_- "The Political Context for Transnational Actor Soft Power: Classical American Overseas Missionary Universities and the State." In China and the World: Theatres of Soft Power, edited by Chitty, Naren and Luo Qing, 161-172. Beijing: Communication University of China, 2015.

. "Private Foreign-Affiliated Universities, the State and Soft Power: The American University of Beirut and the American University in Cairo." Foreign Policy Analysis 8, no. 3 (2012): 293-311. 
-_- . "The University as a Transnational Actor with Transnational Power: American Missionary Universities in the Middle East and China." PS: Political Science \& Politics no. July (2014): 624-627.

Bertelsen, Rasmus Gjedssø, Neema Noori, and Jean-Marc Rickli, eds. Strategies of Knowledge Transfer for Economic Diversification in the Arab States of the Gulf. Berlin \& London: Gerlach Press, 2017.

Briand, Aristide. "Speech/debate in Chambre Des Députés, 20 March 1929." Annales De La Chambre Des Députés (1929): 968-973.

Center for Strategic \& International Studies. Smart Power in the Obama Administration: The Role of International Education and Exchange. Anonymous 2009. Center for Strategic \& International Studies.

Clavin, Patricia. "Defining Transnationalism." Contemporary European History 14, no. 4 (2005): 421-439. doi:10.1017/S0960777305002705.

Dodge, Bayard. The American University of Beirut; a Brief History of the University and the Lands which it Serves. Beirut: Khayat's, 1958.

- - - The American University of Beirut; an Introduction to Beirut and the University. Princeton?: N.J., 1952.

Eddé, Carla. L'USJ: Portrait d'Une Université. Beyrouth: Presses de l'Université Saint-Joseph, 2000.

Fudan University. "Center for American Studies, Fudan University." Fudan University. Accessed 08/09, 2018. http://www.cas.fudan.edu.cn/index.en.php.

Haas, Peter M. "Epistemic Communities." In International Encyclopedia of Political Science, edited by Badie, Bertrand, Dirk Berg-Schlosser and Leonardo Morlino, 788-792. Thousand Oaks, CA: SAGE Publications, 2011.

_-_. "Introduction: Epistemic Communities and International Policy Coordination." International Organization 46, no. 1 (1992): 1-35.

Halliday, Fred. "The Romance of Non-State Actors." In Non-State Actors in World Politics, edited by Josselin, Daphné and William Wallace, 21-37. Basingstoke; New York: Palgrave, 2001.

Hanna, Faith M. An American Mission: The Role of the American University of Beirut. Boston: Alphabet Press, 1979.

Josselin, Daphné and William Wallace. "Non-State Actors in World Politics: A Framework." In Non-State Actors in World Politics, edited by Josselin, Daphné and William Wallace, 1-20. Basingstoke; New York: Palgrave, 2001.

Khalaf, Nadim G. The Economics of the American University of Beirut: A Study of a Private University in the Developing World. Beirut: American University of Beirut, 1977.

Lebanese American University. "History." Lebanese American University. Accessed 08/09, 2018. http://www.lau.edu.lb/about/history/.

Lutz, Jessie Gregory. China and the Christian Colleges 1859-1950. New York: Cornell University Press, 1971.

Makdisi, Ussama Samir. Artillery of Heaven : American Missionaries and the Failed Conversion of the Middle East. The United States in the World. Ithaca: Cornell University Press, 2008.

Ménonville, Corinne de. Les Aventuriers De Dieu Et De La République: Consuls Et Missionnaires En Chine (1844-1937). Paris: Les Indes Savantes, 2007.

Munro, John Murchison. A Mutual Concern: The Story of the American University of Beirut. Delmar, NY: Caravan Books, 1977. 
Murphy, Lawrence R. The American University in Cairo, 1919-1987. Cairo: American University in Cairo Press, 1987.

Nordic Centre. "Nordic Centre." Nordic Centre. Accessed 08/09, 2018. http://www.nordiccentre.org.

Nye, Joseph S. Jr and Robert 0. Keohane. "Transnational Relations and World Politics: An Introduction." International Organization 25, no. 3, Transnational Relations and World Politics (1971): 329-349.

Nye, Joseph S., Jr. Soft Power: The Means to Success in World Politics. 1st ed ed. New York: Public Affairs, 2004.

Nye, Joseph S., Jr. and William A. Owens. "America's Information Edge." Foreign Affairs 75, (1996): 20-36.

Penrose, Stephen Beasley Linnard. That they may have Life; the Story of the American University of Beirut, 1866-1941. Beirut: American University of Beirut, 1970.

Rice, Condoleezza. "Remarks at the U.S. University Presidents Summit on International Education Dinner. Washington DC." . Accessed 11/22, 2006. http://www.state.gov/secretary/rm/2006/58750.htm.

Risse-Kappen, Thomas. "Bringing Transnational Relations Back in: Introduction." In Bringing Transnational Relations Back in: Non-State Actors, Domestic Structures and International Institutions, edited by Risse-Kappen, Thomas, 3. Cambridge: Cambridge University Press, 1995.

Saunier, Pierre-Yves. Transnational History Palgrave Macmillan, 2013.

Sretenovic, Stanislav. "French Cultural Diplomacy in the Kingdom of Serbs, Croats and Slovenians in the 1920s." European Review of History 16, no. 1 (2009): 33-47.

Stone, Diane. "The 'Policy Research' Knowledge Elite and Global Policy Processes." In NonState Actors in World Politics, edited by Josselin, Daphné and William Wallace, 113-132. Basingstoke; New York: Palgrave, 2001.

_-_- "Private Authority, Scholarly Legitimacy, and Political Credibility: Think Tanks and Informal Diplomacy." In Non-State Actors and Authority in the Global System, edited by Higgott, Richard A., Geoffrey R. Underhill and Andreas Bieler, 211-225. London: Routledge, 1999.

The World Bank Group. "Education for the Knowledge Economy." The World Bank Group. Accessed 04/03, 2016. http://go.worldbank.org/I8T7C0VPV0.

Université Saint-Joseph. "Conseil Stratégique [Strategic Council]." Université Saint-Joseph. Accessed 08/09, 2018. https://www.usj.edu.lb/decouvrir/conseilsdeta.htm?code=221.

Vleuten, Erik Van Der. "Toward a Transnational History of Technology: Meanings, Promises, Pitfalls." Technology and Culture 49, no. 4 (2008): 974994.

West, Philip. Yenching University and Sino-Western Relations, 1916-1952. Cambridge, MA: Harvard University Press, 1976.

World Bank. The Road Not Travelled: Education Reform in the Middle East. Washington, DC, 2008. 